\title{
Evaluation of clay soils' permeability: A comparative study between the natural, compacted, and consolidated clay soils
}

\section{Mehmet Şükrü Özçoban ${ }^{1 *}$, Sevgi Güneş Durak ${ }^{2}$, Türkan Ormanci Acar ${ }^{3}$, Güler Türkoglu Demirkol $^{4}$, Suna Özden Çelik ${ }^{5}$, Neşe Tüfekci ${ }^{6}$}

\author{
${ }^{1}$ Faculty of Civil Engineering, Yildiz Technical University, Istanbul, Turkey \\ 2, 4 Faculty of Engineering-Architecture, Nevsehir Hacı Bektas Veli University, Nevsehir, Turkey \\ 3, 6 Faculty of Engineering, Istanbul University, Istanbul, Turkey \\ ${ }^{5}$ Corlu Faculty of Engineering, Namik Kemal University, Tekirdăg, Turkey
}

\author{
Index Terms \\ Compacted Clay \\ Consolidated Clay \\ Leachate \\ Metal Ions \\ Natural Clay \\ Permeability
}

Received: 26 July 2017

Accepted: 6 September 2017

Published: 9 October 2017

\begin{abstract}
Many cities in Turkey use groundwater in order to meet their need of drinking water. Municipal solid waste landfills in all of the cities are major threat for groundwater. Low permeability clay soils by landfill operators are used as a standard practice. However, it has been shown that certain contaminants change the structure of clay soils, making them highly permeable. A lot of investigators have demonstrated that concentrated organic chemicals can alter compacted clays and cause increase in permeability. In this study, the effects of leachates on permeability and the treatment capabilities of the natural, compacted-consolidated, and compacted clay soil have been investigated. Clay soil samples were obtained from the Sile-Komurcuoda landfill area on the Asian side of Istanbul. In the experimental studies, Standard Proctor compaction tests and consolidation tests were applied to the clay soil obtained from the same area. The clay soil samples have permeability $k$ of between $1.10^{-7}$ and $1.10^{-9} \mathrm{~m} / \mathrm{s}$. In order to determine the removal rate of the natural, compacted-consolidated, and compacted clay soil, $\mathrm{Pb}, \mathrm{Cr}, \mathrm{Mn}$, and Fe are measured in the influent and effluent of the lab-scale reactor. The effects of leachates on the permeability of the natural, compacted-consolidated, and compacted clay soil samples have been analyzed. Initially, some decrease has been observed in the clay soil permeability associated with the contamination. The suspended solid matters in the leachates have filled the spaces between the particles of the clay soil pores and this caused a decrease in the permeability. After some time, it is shown that leachates may cause increase in the permeability. The treatment capabilities of the natural, compacted-consolidated, and compacted clay soil samples were quite high. The highest removal rates and the lowest permeability are obtained in natural clay, compacted-consolidated clay, and compacted clay, respectively.
\end{abstract}

(c) 2017 The Author(s). Published by TAF Publishing.

\section{INTRODUCTION}

The infiltration of wastes causes a change in the structure of the leachate later. The composition of leachates is made of rich organic and inorganic pollutants, especially heavy metals $[1,2]$. The leachate serves as an indicator in determining the type of waste. Process formation continues with the presence of contaminants such as hazardous chem- icals, pesticides, and heavy metals in the leachate. $[3,4,5$, 6]. However, many organic substances are biodegradable and are further reduced by aerobic and anaerobic microorganisms [7].

Sililo [8] claimed that organic contaminants are able to move rapidly through the unsaturated zone [2, 8, 9]. Ground and surface water sources exposed metal ions

\footnotetext{
${ }^{*}$ Corresponding author: Mehmet Şükrü Özçoban

†Email: ozcoban@yildiz.edu.tr
} 
which are often seen in landfills leachates $[10,11]$. Removal strategies avoid the migration of these pollutants. Removal of metals is achieved by adsorption with filter materials [11, 12]. It is generally used as clay liners barrier to obstruct leachate transport and water source contamination $[11,13$, 14]. The bottom liner can adsorb metal ions [11]. Leachate includes various organic and inorganic compounds. Therefore, storage areas possess a threat to groundwater $[6,15$, $16]$.

Clay soil is a natural material that reduces hydraulic conductivity in landfills. Clay soil and uncompacted clay soil, which are frequently found in the nature, are the key components of the landfills. [17]. Given their high impermeability, clay soil is often used as pollution barrier for waste storage sites $[1,18,19]$. In most cases, the nature of clay soil that seals the site floor is a criterion for selecting the landfill site [1].

Contamination of soil and groundwater from the landfill is prevented by utilizing a system of composite liner including compressed clay soil or geosynthetic clay liner [20]. Compacted clay soil is preferred because it is low-cost and provides leachate treatment with high efficiency [21, 22]. Although the compacted clay soils have many superiorities like low permeability $\left(<10^{-9} \mathrm{~m} / \mathrm{s}\right)$, they have instability problems because of their potential of high shrinkage and expansion [22, 23, 24]. According to the design criteria of Turkish Solid Waste Management Legislation, the liner component is compacted to provide a hydraulic conductivity no greater than $10^{-9} \mathrm{~m} / \mathrm{s}$ [25].

The composition of leachates changes over time due to the evolution process of waste degradation which is strongly linked to the mechanical-chemical and biological reaction taking place in the landfill [1]. The leachate quality changes corresponding to such factors as the type of waste, climatic factors, area hydrogeology, waste settlement, and type of cover material. The clay soils in the landfills may cause an increase in hydraulic conductivity over time due to water pressure [21]. Sivapullaiah et al. [25, 26] determined that the permeability of soils decreases with increasing content of smaller particles.

In the experimental studies, the effects of leachates on permeability and the treatment capability of natural clay, compacted consolidated clay, and compacted clay soil have been investigated. Clay soil samples were obtained from the Sile-Komurcuoda landfill on the Asian side of Istanbul. Standard proctor compaction tests and consolidation tests were applied to the clay soil. The soil samples have a permeability, k, between $1.10^{-7}$ and $1.10^{-9} \mathrm{~m} / \mathrm{s}$. Aiming to determine the removal rate of the natural clay, compacted- consolidated clay, and compacted clay soil, $\mathrm{Pb}, \mathrm{Cr}, \mathrm{Mn}$, and Fe are measured in the influent and effluent of the lab-scale reactor.

\section{MATERIALS AND METHODS}

In this study, standard proctor compaction tests and consolidation tests were performed to the clay soil obtained from the Sile-Komurcuoda landfill area. Additionally, natural clay soil was also used without any treatment. Aiming to determine the removal rate of the natural clay, compactedconsolidated clay, and compacted claysoil, $\mathrm{Pb}, \mathrm{Cr}, \mathrm{Mn}$, and Fe are measured in the influent and effluent of the lab-scale reactor. Chemical, physicochemical, and sieve analyses of clay soil have been taken from previous studies [27]. The aim of this paper has been carried out in two stages:

- In the first stage, clay soil taken from the Sile-Komurcuoda landfill site has been compacted, consolidated, and the permeability of the leachate has been investigated.

- In the second stage, $\mathrm{Pb}, \mathrm{Cr}, \mathrm{Mn}$, and $\mathrm{Fe}$ analyses have been carried out to determine the treatment capacity of the natural clay, compacted-consolidated clay, and compacted clay soil. These analyses have been conducted on the samples taken from the influent and effluent of the reactors.

\section{A. Experimental Setup}

Constant-head permeameters experimental methods were used in this study [28]. Reactors, which were made of plexiglass materials (Figure 1), were filled with natural clay, compacted-consolidated clay, and compacted clay soil. Using distilled water as a permeant, permeabilities $(k)$ were determined in 3-4 weeks to ensure proper column behavior. Permeability $(k)$ was found to be: water, $5.284 \times 10^{-9}$, leachate, $2.64 \times 10^{-8} \mathrm{~m} / \mathrm{s}$. Samples were taken from the soil and transferred to the laboratory and then pressed into the permeability reactor. In order to prevent the swell (expansion) of the clay soil in the apparatus, pieces of gravel were placed upon it. Meanwhile, a perforated plexiglass filter has been placed on and under the soil sample together with the filter papers. The mold reactor tests were performed by flowing the liquid downward through the $100 \mathrm{~mm}$ diameter natural clay, compacted-consolidated clay, and compacted clay specimens (Figure 1). Height of the clay soil specimens was $110 \mathrm{~mm}$. Clay soil specimens were saturated under 0.3 bar pressure. Permeability tests were performed with water. After 3-4 weeks, water was replaced by leachate. Figure and photograph of experimental setup are given in Figure 1. 


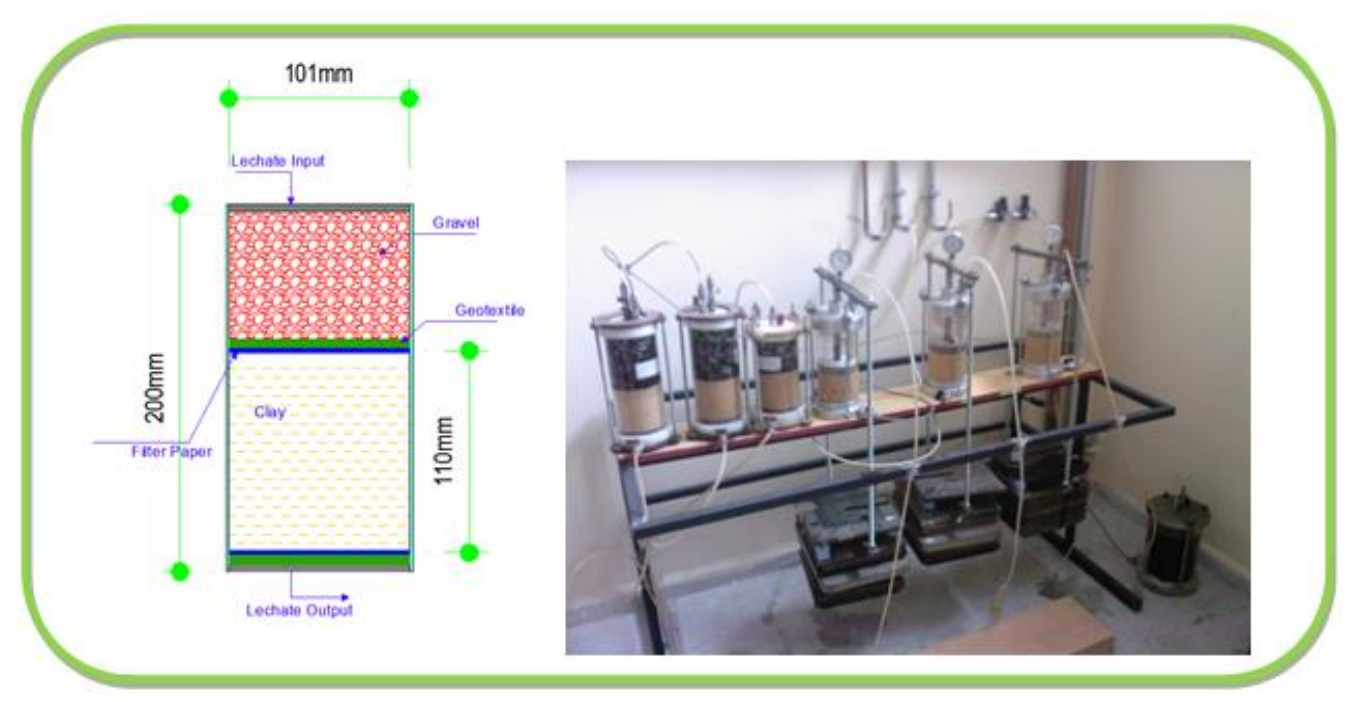

Fig. 1. Experimental setup

\section{B. Permeability Tests}

Constant-head tests have been performed to calculate the permeability of the clay soil using Equation 1:

$k=\frac{Q L}{A t\left(h_{1}-h_{2}\right)}$

where $k$ is the permeability coefficient $(\mathrm{cm} / \mathrm{s}), A$ is the surface area of specimen $\left(\mathrm{cm}^{2}\right), L$ is the distance between the manometers ( $\mathrm{cm}), Q$ is the total discharge $\left(\mathrm{cm}^{3} / \mathrm{s}\right)$, and $t$ is the elapsed time $(s)$.

\section{Standard Proctor Compaction Test}

Standard Proctor Compaction Testing is performed using the method ASTM D 698/AASHTO T99 [29] in the laboratory.

\section{Consolidation Test}

The consolidation test is based on the standard method (ASTM D2435-04) which has been designed to correct for the effects of sampling disturbance [30].

\section{E. Effluent Analysis}

Aiming to determine the attenuation capacity of the natural clay, compacted-consolidated clay, and compacted clay soil $\mathrm{Pb}, \mathrm{Cu}, \mathrm{Mn}$, and Fe have been measured based on Standart APHA Methods in the influent and effluent of the continuous reactor [31].

\section{RESULTS AND DISCUSSION}

In this research, permeability and the removal rate for the $\mathrm{Pb}, \mathrm{Cr}, \mathrm{Mn}$, and $\mathrm{Fe}$ have been investigated for the leachate taken from the Sile Komurcuoda Organized landfill site and the natural samples and the disturbed samples taken from the same place and natural soil samples, compacted with the standard compaction methods and compacted and consolidated soil samples. The results obtained are presented below. Chemical, physicochemical, and sieve analyses of clay soil have been taken from previous studies $[27,28]$.

\section{A. Physico-Chemical Properties of the Clay}

The clay soil was taken from Komurcuoda landfill site which is located in partially or totally abandoned mine quarry areas with damaged native soil surfaces. The clay is taken from a slightly inclined valley covered with Neogene aged layers of clay soil, sand, gravel, and coal lenses. The clay soil is chemically compatible with the fill area. The thickness of the clay liner underlying domestic solid wastes stored in the Komurcuoda solid waste landfill site is $60 \mathrm{~cm}$ and its permeability factor is between $1 \times 10^{-7}$ and $1 \times 10^{-8} \mathrm{~m} / \mathrm{s}[27,32,33,34,35]$. Colour of soil samples was brownish-gray. The clay samples that are taken from the site mentioned are made of kaolinite $68-71 \%$, free quartz 6-9\%, illite $15-18 \%$, and others $2-5 \%$. The kaolinite and illite are considered to be true clay soil minerals. The soil samples have the permeability $\mathrm{k}=1 \times 10^{-8} \mathrm{~m} / \mathrm{s}$ and a discharge loss of $8.5-9 \%$, and water of $0.2-0.4 \%[27,28]$. 


\section{B. Properties of the Leachate}

The characteristics of the leachate have been investigated. The results of the characterization studies are pre- sented in Table 1. Leachate has a colour of dark brown and includes very small granules and also large amounts of organic and inorganic contaminants, and a high concentration of metals.

TABLE 1

PROPERTIES OF THE LEACHATE

\begin{tabular}{lccccc}
\hline \hline Parameter/Averages & $\mathrm{pH}$ & $\begin{array}{c}\mathrm{Pb} \\
(\mathrm{mg} / \mathrm{L})\end{array}$ & $\begin{array}{c}\mathrm{Cr} \\
(\mathrm{mg} / \mathrm{L})\end{array}$ & $\begin{array}{c}\mathrm{Mn} \\
(\mathrm{mg} / \mathrm{L})\end{array}$ & $\begin{array}{c}\mathrm{Fe} \\
(\mathrm{mg} / \mathrm{L})\end{array}$ \\
\hline Samples & 7.9 & 0.6 & 1.8 & 4.8 & 38.25 \\
\hline \hline
\end{tabular}

\section{B. Results of the Compaction, Consolidation, and Perme- ability Tests}

The compaction in the laboratory determines experimentally the change fullness of dry unit weight with the content of water and indicates the packing degree under certain compaction energy. The compaction experiments were conducted for the clay soil used in filling. Standard and modified compaction tests are the two most commonly used methods of compaction tests. The results of the experiment performed to obtain the correlation between the water content of the soil and compacted dry density are given in Table 2 and Figure 2. Figure 3 shows the stress and strain curves of the samples to which consolidation was applied.

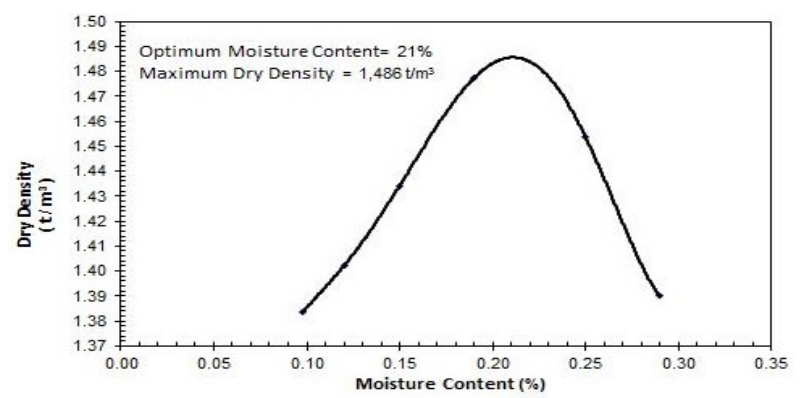

Fig. 2 . Moisture content and dry density relationship

TABLE 2

COMPACTION STUDY RESULTS

\begin{tabular}{lccccccc}
\hline \hline $\begin{array}{l}\text { Sample } \\
\text { place }\end{array}$ & $\begin{array}{c}\text { Volume of container } \\
\left(\mathrm{cm}^{3}\right)\end{array}$ & $\begin{array}{c}\text { Diameter } \\
(\mathrm{cm})\end{array}$ & $\begin{array}{c}\text { Height } \\
(\mathrm{cm})\end{array}$ & $\begin{array}{c}\text { Number } \\
\text { of layers }\end{array}$ & $\begin{array}{c}\text { Weight } \\
\text { of hammer }\end{array}$ & $\begin{array}{c}\text { Height } \\
\text { of drop }\end{array}$ & $\begin{array}{c}\text { Number } \\
\text { of strike }\end{array}$ \\
\hline Komurcuoda & $1000 \mathrm{~cm}^{3}$ & $10.47 \mathrm{~cm}$ & $11.56 \mathrm{~cm}$ & 3 & 2.5 & 30.5 & 25 strikes for every layer \\
\hline \hline
\end{tabular}

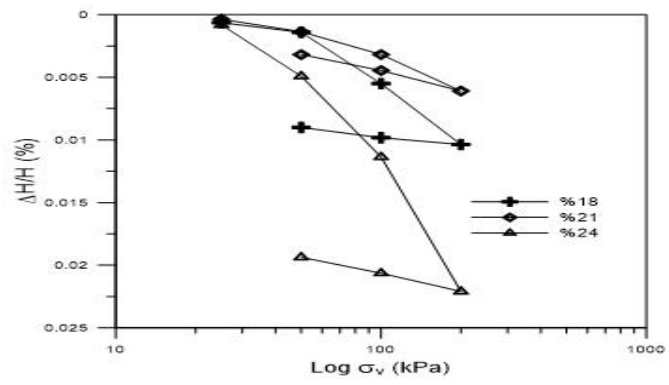

Fig. 3 . Oedometer stress and strain test relation

The experiments were performed in the laboratory to determine the effects of $\mathrm{Pb}, \mathrm{Cr}, \mathrm{Mn}$, and Fe on permeability of clay soil for about 220 days. Permeabilities are determined by performing the experiments on compacted clay

and compacted-consolidated clay samples by different energy applications in the laboratory. Permeability experiments were performed on the samples that were prepared at the optimum water content, over $3 \%$ and under $3 \%$ of the optimum water content, obtained as a result of the standard compaction application. Then permeability measurements were carried out, where leachate was passed through the samples. The same procedures were repeated on the samples prepared by applying consolidation with the standard compaction and natural clay soil.

As seen in Figure $4(a, b, c)$, changes were observed in the permeability of the natural, compacted-consolidated, and compacted clay samples. Initally, the suspended solids, metal ions, and microrganisms within leachate were seen to decrease the permeability by filling the void spaces among 
the particles of the clay soil. The permeability decreased significantly with time (up to $29^{\text {th }}$ day), since the permeating liquid microorganism growth inside the soil pores caused pore clogging and suspended solids, and precipitated some metal ions to fill the void spaces among the particles of the compacted clay soils. However, some deformations occur in the structure of clay soil due to the presence of very high concentration and a variety of pollutants in leachate. These deformations lead to an increase in the permeability of clay soils over time (after the $29^{\text {th }}$ day).

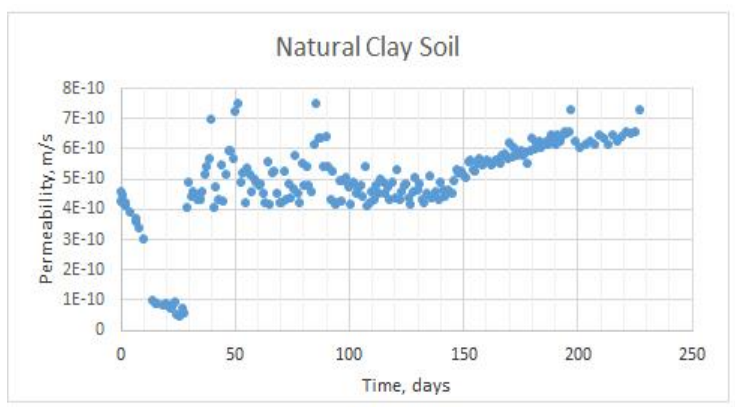

(a)

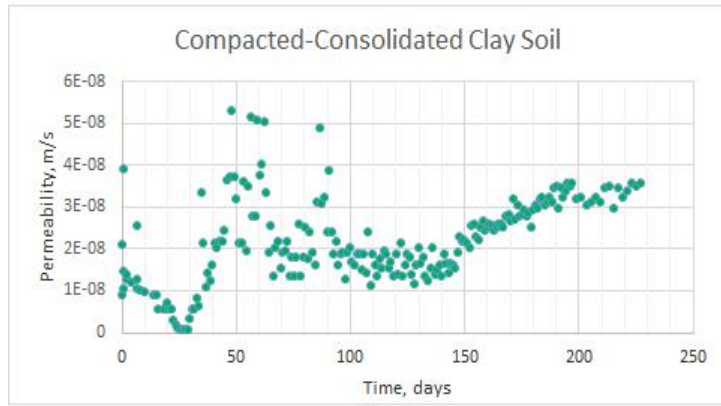

(b)

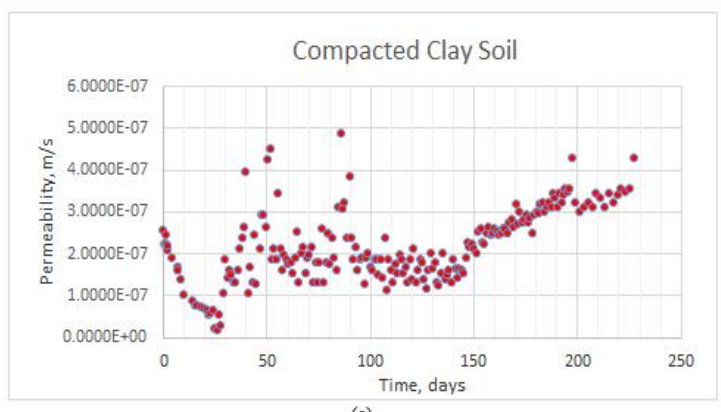

(c)

Fig. 4 . Permeability and Time Relation

In addition, it was also observed that leachate passed faster through samples to which standard compaction was applied only and passed with more difficulty through compacted-consolidated samples. Leachate gets through with a slower rate in natural clay soil, while the permeability of compacted samples was seen to be at the level of $10^{-7}$ $\mathrm{m} / \mathrm{s}$, that of compacted-consolidated samples was at the level of $10^{-8} \mathrm{~m} / \mathrm{s}$, and the permeability of natural clay soil was found as $10^{-10} \mathrm{~m} / \mathrm{s}$.

\section{Effluent Analysis Results of the Landfill Leachate in the Clay Soil}

Effluent analysis results for $\mathrm{Pb}(\mathrm{II}), \mathrm{Cr}(\mathrm{II}), \mathrm{Mn}(\mathrm{II})$, and $\mathrm{Fe}(\mathrm{II})$ are shown in Figure 5 (a, b, c, d). The initial Pb(II) value of leachate was $0.6 \mathrm{mg} / \mathrm{L}$. The first passage of leachate through natural clay soil was observed on the $40^{t} h$ day. The time required for compacted and consolidated clay soil is about 35 days and for compacted clay soil, it is about 28 days. $\mathrm{Pb}$ (II) effluent value was $0.16 \mathrm{mg} / \mathrm{L}$ and removal efficiency was $73 \%$ on the $90^{\text {th }}$ day in the reactor filled with natural clay. On the same age-day for the compacted and compacted-consolidated samples, $\mathrm{Pb}$ (II) effluent value was $0.23 \mathrm{mg} / \mathrm{L}$ and the removal efficiencies of $62 \%$ by standard compaction with $21 \%$ humidity (optimum humidity rate) can be located. Removal rate efficiencies were monitored for 220 days. The leachate's breakpoint for clay soil occured at the end of the three months. Figure 5 a shows that removal rate efficiency increases until the $90^{t} h$ day; afterwards, it decreases. The reason for this variation can be the adsorption until the turning point, then desorption begins. $\mathrm{Pb}$ (II) removal efficiency was observed to be quite high for natural clay.

The influent $\mathrm{Cr}(\mathrm{II})$ value of leachate obtained experimentally was $1.8 \mathrm{mg} / \mathrm{L}$. For the natural clay at the end of the third month, removal efficiency and Cr(II) effluent values were $92 \%$ and $0.14 \mathrm{mg} / \mathrm{L}$, respectively. For compacted and consolidated clay soil in the same period of time, the removal efficiency was found as $89 \%$ and the $\mathrm{Cr}$ (II) effluent value as $0.19 \mathrm{mg} / \mathrm{L}$. The efficiency value is $82 \%$ and effluent value is $0.32 \mathrm{mg} / \mathrm{L}$ for the compacted clay soil on the $90^{t} h$ day. Removal rate was meassured for 220 days. During the first 90 days, removal rate went up; afterwards, it went down. This can be explained by the same reason as in the part of removal of $\mathrm{Pb}$. 


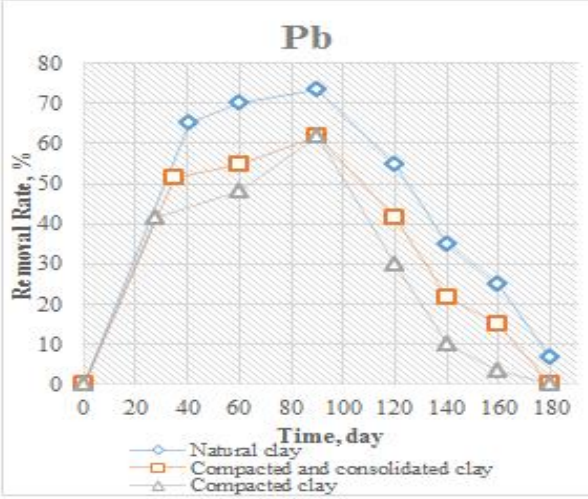

(a) $\mathrm{Pb}$

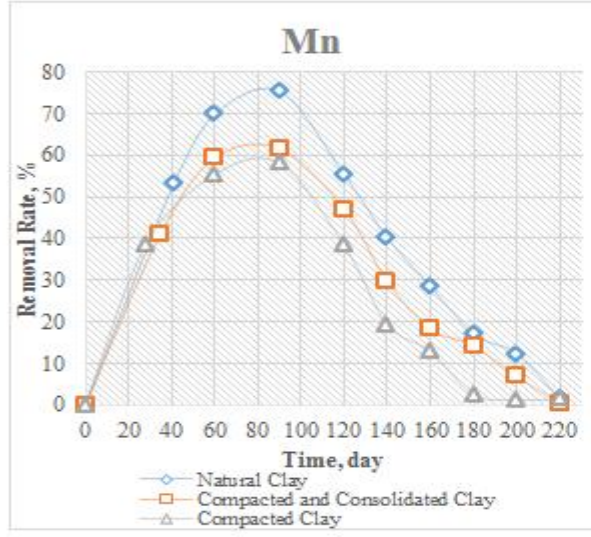

(c) $\mathrm{Mn}$

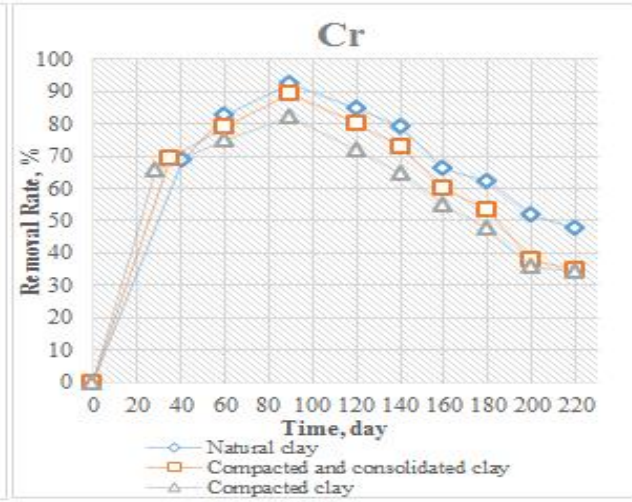

(b) $\mathrm{Cr}$

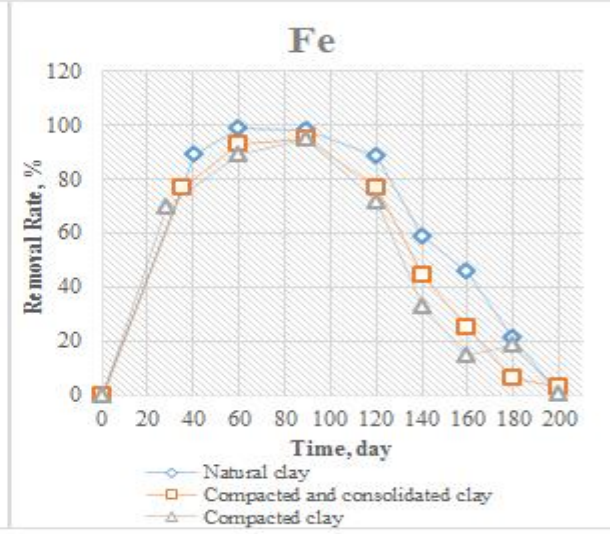

(d) $\mathrm{Fe}$

Fig. 5 . The removal rate of $\mathrm{Pb}(\mathrm{a}), \mathrm{Cr}(\mathrm{b}), \mathrm{Mn}(\mathrm{c})$, and $\mathrm{Fe}(\mathrm{d})$

The experimentally obtained influent $\mathrm{Mn}$ (II) value of leachate was $4.8 \mathrm{mg} / \mathrm{L}$. Mn(II) effluent value was obtained as $1.18 \mathrm{mg} / \mathrm{L}$ and removal efficiency as $75 \%$ on the $90^{\text {th }}$ day in the reactor for natural clay. For compacted-consolidated clay soil samples, the Mn(II) effluent value was meassured as $1.84 \mathrm{mg} / \mathrm{L}$ and removal efficiency as $62 \%$ on the $90^{\text {th }}$ day. $2.01 \mathrm{mg} / \mathrm{L}$ is the determined $\mathrm{Mn}$ (II) effluent value and $58 \%$ is the removal efficiency on the $90^{\text {th }}$ day in the samples compacted by standard compaction. However, as it can be seen in Figure 5, the removal efficiency of Mn(II) was seen to increase generally until the $90^{\text {th }}$ day and it began to decrease in the following days. This change can be explained so that adsorption turns to desorption after the $90^{\text {th }}$ day. Mn(II) removal efficiency was observed to be quite high for natural clay.

The influent Fe(II) value of leachate is obtained experimentally as $38.25 \mathrm{mg} / \mathrm{L}$. Fe(II) effluent value was 0.54 $\mathrm{mg} / \mathrm{L}$ and removal efficiency as $99 \%$ on the $60^{\text {th }}$ day in the reactor with the natural clay sample. For compacted and consolidated clay soil, $2.05 \mathrm{mg} / \mathrm{L}$ is the Fe(II) effluent value and removal efficiency is $95 \%$ at the end of the third month. For compacted clay soil, $2.01 \mathrm{mg} / \mathrm{L}$ is the Fe(II) effluent value and removal efficiency is $95 \%$ on the $90^{\text {th }}$ day in the reactor with clay sample compacted by standard compaction with $21 \%$ humidity (optimum humidity rate). Removal was monitored for 200 days. However, as it clearly can be seen in Figure 5, the removal efficiency of Fe(II) was seen to increase generally until the $60^{t h}$ day for natural clay and $90^{\text {th }}$ day for compacted-consolidated and compacted clays and began to decrease in the following days. This change can be explained by adsorption until the $60^{t h}$ and the $90^{t h}$ day followed by desorption. Fe(II) removal efficiency was observed to be quite high in the study examining the removal of natural clay.

\section{CONCLUSION}

In this study, high removal efficiencies have been obtained after leachate passes through clay samples and it has been observed that the clay has a natural purification capacity. It has been observed that the suspended matters in the leachate filled the spaces between the clay particles and 
the growth of microorganisms inside the soil pores caused pore clogging which led the permeability to decrease. In the long term, it is expected that this variation would take place in the reverse direction. In other words, the permeability would increase. It is considered that this variation would be the result of the certain chemical and physical deteriorations produced by the contaminative components in the leachate.

\section{ACKNOWLEDGMENT}

This study was supported by the Research Fund of Istanbul University, Project number BEK- 2017-25403.

\section{REFERENCES}

[1] I. Ghorbel-Abid and M. Trabelsi-Ayadi, "Competitive adsorption of heavy metals on local landfill clay," Arabian Journal of Chemistry, vol. 8, no. 1, pp. 25-31, 2015. DOI: $10.1016 /$ j.arabjc.2011.02.030

[2] J. Frederick, "Evaluation of contaminant containment at Regina Landfill," Ph.D. thesis, University of Regina, Regina, Saskatchewan, 2014.

[3] T. H. Christensen, P. Kjeldsen, P. L. Bjerg, D. L. Jensen, J. B. Christense, A. Baun, H. J. Albrechtsen and G. Heron, "Review: Biogeochemistry of landfill leachate plume," Applied Geochemistry, vol. 16, no. 7, pp. 659-718, 2001.

[4] P. Kjeldsen, M. A. Barlaz, A. P. Rooker, A. Baun, A. Ledin and T. H. Christensen, "Present and long-term composition of MSW landfill leachate: A review," Critical Reviews in Environmental Science and Technology, vol. 32, no. 4, pp. 297-336, 2002.

DOI: $10.1080 / 10643380290813462$

[5] R. J. Slack, J. R. Gronow and N. Voulvoulis, "Household hazardous waste in municipal landfills: Contaminants in leachate," Science of the Total Environment, vol. 337, no. 1-3, pp. 119-137, 2005.

DOI: $10.1016 /$ j.scitotenv.2004.07.002

[6] G. Varank, A. Demir, E. Adar, M. S. Bilgili, S. Top, S. Yazici Guvenc and M. S. Ozcoban, "Investigation of liner systems in transport of organic and inorganic contaminants in sanitary landfill: A case study," Clean-Soil Air Water, vol. 45, no. 1, pp. 1-8, 2017.

DOI: $10.1002 /$ clen.201500198

[7] M. El-Fadel, A. N. Findikakis and J. O. Leckie, "Environmental impacts of solid waste landfilling," Journal of Environmental Management, vol. 50, pp. 1-25, 1997.

[8] 0. T. N. Sililo, "Migration and attenuation of organic contaminants in the unsaturated zone through field experi- ments in the Western Cape, South Africa." pp. 181-185, Rotterdam, Netherlands: ITP Publishing, 1997.

[9] V. I. Pye and J. Kelly, "The extent of groundwater contamination in the United States." Philadelphia, PA: The Academy of Natural Sciences, 1987.

[10] T. H. Christensen, R. Cossu and R. Stegman, "Sanitary landfilling: Process, technology and environmental impact," pp. 19-25, London, UK: Academic Press, 1989.

[11] T. B. Mussoa, M. E. Parolob, G. Pettinarib and F. M. Francisca, "Cu(II) and $\mathrm{Zn}(\mathrm{II})$ adsorption capacity of three different clay liner materials," Journal of Environmental Management, vol. 146, pp. 50-58, 2014.

DOI: $10.1016 /$ j.jenvman.2014.07.026

[12] R. Reddy, T. Xie and S. Dastgheibi, "Removal of heavy metals from urban stormwater runoff using different filter materials," Journal of Environmental Chemical Engineering, vol. 2, no. 1, pp. 282-292, 2014.

DOI: $10.1016 /$ j.jece.2013.12.020

[13] J. Cuevas, A.I. Ruiz, I. S. de Soto, T. Sevilla, J. R. Procopio, P. Da Silva, M. J. Gismera, M. Regadío, N. Sánchez Jiménez, M. Rodríguez Rastrero and S. Leguey, "The performance of natural clay as a barrier to the diffusion of municipal solid waste landfill leachates," Journal of Environmental Management, vol. 95, pp. S175-S181, 2012. DOI: 10.1016/j.jenvman.2011.02.014

[14] R. Cossu, "Groundwater contamination from landfill leachate: When appearances are deceiving," Waste Management, vol. 33, no. 9, pp. 1793-1794, 2013.

DOI: 10.1016/j.wasman.2013.07.002

[15] El-Fadel, A. N. Findikakis and J. O. Leckie, "Environmental impacts of solid waste landfilling," Journal of Environmental Management, vol. 50, no. 1 pp. 1-25, 1997.

[16] T. B. Edil, "A review of aqueous-phase voc transport in modern landfill liners," Waste Manage, vol. 23, no. 7, pp. $561-571,2003$.

DOI: $10.1016 /$ s0956-053x(03)00101-6

[17] H. E. Srasra, "Hydraulic conductivity study of compacted clay soils used as landfill liners for an acidic waste", Waste Management, vol. 33, no. 1, pp 60-66, 2013. DOI: $10.1016 /$ j.wasman.2012.08.012

[18] K. Bellir, M. Bencheikh-Lehocine, A. H. Meniai and N. Gherbi, "Study of the retention of heavy metals by natural material used as liners in landfills," Desalination, vol. 185, no. 1-3, pp. 111-119, 2005.

DOI: $10.1016 /$ j.desal.2005.03.074

[19] I. K. Kouamel, D. L. Gone, I. Savane, E. A. Kouassi, K. Koffi, B. T. A. Goula and M. Diallo, "Mobilité relative des métaux lourds issus de la décharge d'A kouédo et risque 
de contamination de la nappe du continental terminal (Abidjan .Côte d'Ivoire)," Afrique Science: Revue Internationale des Sciences et Technologie, vol. 02, no. 1, pp. 39-56, 2006. DOI: 10.4314/afsci.v2i1.61133

[20] A. A. Aldaeef and M. T. Rayhani, "Hydraulic performance of Compacted Clay Liners (ccls) under combined temperature and leachate exposures," Waste Management, vol. 34, no. 12, pp. 2548-2560, 2014.

DOI: 10.1016/j.wasman.2014.08.007

[21] E. A. M. Yahia, A. Al. R. Amer, Y. Al. A. Mohammed, Q. Ahmed and Al. R. Abdul-Hamid, "Assessment of crushed shales for use as compacted landfill liners engineering," Engineering Geology, vol. 80, no. 3-4, pp. 271-281, 2005. DOI: $10.1016 /$ j.enggeo.2005.06.001

[22] J. K. Mitchell, "Fundamentals of soil behaviour," New York, NY: John Wiley \& Sons Inc., 1993.

[23] C. Di Maio, L. Santoli and P. Schiavone, "Volume change behaviour of clays: The influence of mineral composition, pore fluid composition and stress state," Mechanics of Materials, vol. 36, no. 5-6, pp. 435-451, 2004. DOI: $10.1016 / \mathrm{s} 0167-6636(03) 00070-\mathrm{x}$

[24] M. S. Ozcoban, N. Cetinkaya, S. O. Celik, G. T. Demirkol, V. Cansiz and N. Tufekci, "Hydraulic conductivity and removal rate of compacted clays permeated with landfill leachate," Desalination and Water Treatment, vol. 51, no. 31/33, pp. 6148-6157, 2013.

DOI: $10.1080 / 19443994.2013 .769662$

[25] V. Sivapullaiah, A. Sridharan and V. K. Stalin, "Hydraulic conductivity of bentonite-sand mixtures," Canadian Geotechnical Journal, vol. 37, no. 2, pp. 406-413, 2000. DOI: $10.1139 / \mathrm{t} 11-042$

[26] P. Roya, R. Hadi, A. Hossein and M. Vahedian, "Survey of wastewater stabilization pond potential in meeting environmental standards," International Journal of Applied and Physical Sciences, vol. 1, no. 1, pp. 19-21, 2015. DOI: $10.20469 /$ ijaps.50003
[27] N. Tufekci, M. Ozcoban, S. Yalcın, Y. Ascı and C. Akgüner, "Adsorption and permeability of clays permeated with ferrous iron and manganese," Fresenius Environmental Bulletin, vol. 19, no. 8, pp. 1703-1714, 2010.

[28] K. Ozaydın, S. Yıldırım and M. Yıldırım, "Geotechnical report on the ba-ii cell of Komurcuoda Landfill site located in the Asian side of Istanbul," Ph.D. thesis, Yildiz Technical University, Istanbul, Turkey, 1996.

[29] American Society for Testing and Materials, "Soil and rock: Building stone," pp. 202-284, Philadelphia, PA, 1982.

[30] American Society for Testing and Materials, "Standard test methods for one-dimensional consolidation properties of soils using incremental loading," 2004 [Online]. Available: goo.gl/Bcxnwa

[31] A. E. Greenberg, "Standard methods for the examination of water and wastewater," Washington, DC, WA: American Public Health Association, 2005.

[32] M. Ş. Ozcoban, "Permeability and removal rate of compacted clays to organic and inorganic matters," Journal of Scientific and Industrial Research, vol. 67, no. 2, pp. 136-143, 2008.

[33] S. Ylldız, "Report on the renovation project for Komurcuoda landfill," 2000 [Online]. Available: goo.gl/SHTFzK

[34] T. M. Mahmoud, "The effect of different types of soils on the germination rate of the watercress seeds (nasturtium officinal)," International Journal of Applied and Physical Sciences, vol. 2, no. 1, pp. 21-32, 2016.

DOI: $10.20469 /$ ijaps.2.50004-1

[35] B. R. Koh, Y. Hun Oh and D. Park, "A study on formation of saltwater-freshwater interface and upconing in coastal aquifers based on experiments with hydraulic models," Journal of Advances in Technology and Engineering Studies, vol. 2, no. 5, 134-139, 2016.

DOI: $10.20474 /$ jater-2.5.1

— This article does not have any appendix. — 